\title{
TENTANG REALITAS DARI SEGALA SESUATU
}

\section{Agus Hasan Budiyanto}

Department of Mathematics, College of Mount Saint Vincent, Riverdale, NY, USA.

Email: agus.budiyanto@cmsv.edu

\section{Abstrak}

Fokus pembahasan dalam artikel ini berisi analisis tentang realitas, dari level yang paling rendah ke yang paling tinggi, berdasarkan ilmu Fisika, Metamatematika dan The Higher Infinite. Teorema ketidaklengkapan akan memainkan peranan penting dalam pembahasan ini. Sebagai penerapan analisis tersebut, dalam artikel ini akan dibahas penafsiran dari pengalaman mistik Jalaluddin Rumi tentang realitas melalui puisinya yang berjudul "A Garden Beyond Paradise". Dalam puisi ini, Rumi menekankan bahwa ada realitas yang jauh lebih tinggi dan agung dari surga, yakni realitas ketuhanan. Manusia seharusnya tidak puas hanya dengan surga, melainkan tetap meneruskan perjalanan ruhaninya sampai menyatu dengan Tuhan.

Kata kunci: M-theory, The Mathematical Universe Hypothesis, Metamatematika, The Higher Infinite.

\section{Abstract}

The focus of the discussion in this article contains an analysis of reality, from the lowest level to the highest, based on physical science, Metamathematics and The Higher Infinite. Incompleteness theorem will play an important role in this discussion. As an application of such analysis, it will be discussed in this article the interpretation of Jalaluddin Rumi's mystical experience of reality via his poem entitled "A Garden Beyond Paradise". In this poem, Rumi emphasized that there is a reality that is much higher and greater than paradise, namely the reality of the Godhead. Human should not be satisfied with just paradise, he should continue his spiritual journey to unite with the Godhead.

Keywords: M-theory, The Mathematical Universe Hypothesis, Metamathematics, The Higher Infinite. 


\section{PENDAHULUAN}

Setiap pembahasan menyeluruh tentang realitas harus mencakup pembahasan tentang alam semesta. Pengetahuan manusia modern tentang alam semesta diberikan oleh sains, terutama oleh ilmu fisika. Filsafat juga memainkan peranan penting dalam memahami alam semesta. Ilmu fisika dan filsafat pada kenyataannya bukan dua bidang yang terpisah, paling tidak sebelum 1687 saat Isaac Newton menerbitkan karyanya yang masyhur "Philosophiae Naturalis Principia Mathematica" atau prinsip-prinsip matematika dari filsafat alam semesta. Dalam karya ini, Newton dengan jelas memandang ilmu fisika sebagai salah satu cabang dari filsafat.

Perkembangan ilmu fisika sejak awal menunjukkan bahwa matematika merupakan persyaratan mutlak untuk merumuskan teori-teori fisika. Newton harus menciptakan kalkulus untuk merumuskan teori mekanika klasik. Semakin luas ruang lingkup teori fisika, semakin tinggi level kompleksitas dari matematika yang diperlukan. Untuk merumuskan mekanika kuantum dan teori medan kuantum, fisikawan teoretik memerlukan konsep-konsep matematika lanjut seperti Hilbert spaces, Path integral, C* algebra, dll. Albert Einstein memerlukan Riemannian geometry untuk merumuskan teori relativitas umum pada tahun 1915. Saat ini fisikawan teoretik memerlukan matematika dengan kompleksitas yang jauh lebih tinggi lagi untuk merumuskan teori Superstring. Bahkan sebelum Newton menerbitkan Principia, Galileo Galilei sudah mengantisipasi hal ini dengan mengatakan bahwa matematika adalah bahasa yang digunakan Tuhan untuk menulis hukum-hukum alam: "Mathematics is the language in which God has written the universe".

Karena perumusan hukum-hukum alam tidak mungkin dikerjakan tanpa menggunakan matematika, maka pembahasan yang menyeluruh tentang realitas harus juga mencakup pembahasan tentang matematika. Beberapa fisikawan bahkan mempercayai bahwa matematika sesungguhnya bukan hanya bahasa dalam memahami realitas, tetapi adalah juga realitas itu sendiri. Sehingga usaha manusia untuk memahami realitas melalui sains adalah identik dengan usaha manusia untuk memahami hakekat matematika. 
Tetapi apakah sains, terutama ilmu fisika, dapat menjelaskan realitas dengan tuntas? Banyak fisikawan yang mempercayai keberadaan teori pamungkas yang bisa menjelaskan seluruh realitas dengan tuntas, teori yang bisa menjelaskan segala-galanya termasuk eksistensi Tuhan. Teori ini disebut dengan Theory of Everything (ToE). Stephen Hawking adalah fisikawan terkenal yang mempercayai keberadaan ToE, meskipun Stephen Hawking sendiri mengubah pandangannya tersebut di kemudian hari (Hawking, 2002).

Dalam artikel ini akan dijelaskan bahwa sains tidak mungkin bisa menjelaskan realitas dengan tuntas. Hal ini akan dijelaskan melalui teorema ketidaklengkapan yang pertama kali dibuktikan oleh Kurt Godel. Juga akan didiskusikan dalam artikel ini bahwa pemahaman lengkap dari realitas hanya mungkin apabila digunakan pendekatan The Higher Infinite. Sebagai penerapan analisis tersebut, pengalaman mistik dari Jalaluddin Rumi tentang realitas akan diberikan tafsirnya dengan memakai The Higher Infinite.

Pembahasan dalam artikel ini akan dibagi menjadi empat bagian sebagai berikut. Bagian pertama akan membahas konsep tentang realitas menurut ilmu fisika. Selanjutnya bagian kedua akan disikusikan tentang matematika dan teorema ketidaklengkapan Godel. Pada bagian ketiga paper ini akan menelaah pengenalan tentang Metamatematika dan The Higher Infinite. Di bagian empat artikel ini akan diakhiri dengan analisa mengenai realitas menurut Jalaluddin Rumi.

\section{REALITAS MENURUT ILMU FISIKA}

Menurut penafsiran standar dari mekanika kuantum, kesadaran manusia berperanan sangat penting dalam proses penciptaan realitas yang diamati oleh manusia (Rosenblum and Kuttner, 2006). Realitas tersebut hanya ada saat dan setelah dilakukan pengamatan. Realitas yang diamati tersebut diciptakan melalui proses refleksi atau proyeksi dari kesadaran yang ada dalam diri manusia. Berdasarkan "The Holographic Principle" dalam konteks teori Superstring dijelaskan bahwa proyeksi tersebut dapat dipandang kirakira mirip hologram (Susskind, 1995). 
Dalam sebuah anekdot tentang Albert Einstein, dikisahkan bahwa ia bertanya secara retoris kepada sahabatnya, Abraham Pais: "Apakah kamu yakin bulan sudah berada di atas sana, sesaat sebelum kamu melihatnya?". Reaksi Einstein ini mirip reaksi orang awam yang masih sangat sulit menerima penafsiran mekanika kuantum. Sepertinya ia masih meragukan apakah mekanika kuantum bisa diterapkan secara langsung kepada benda-benda makro seperti bulan, bintang dan galaksi.

Meskipun Einstein meragukan kebenaran dari penafsiran mekanika kuantum (misalnya melalui eksperimen Einstein-PodolskyRosen), Einstein pernah mengatakan bahwa realitas adalah ilusi: "Reality is merely an illusion, albeit a very persistent one". Kutipan ini tampaknya bukan mengacu kepada mekanika kuantum, melainkan kepada teori relativitas umum ciptaan Einstein sendiri, setelah Kurt Godel menemukan solusi dari relativitas umum yang memberi implikasi bahwa konsep aliran waktu adalah ilusi (Yourgrau, 2006). Berdasarkan biografinya, Kurt Godel adalah sahabat dekat Einstein yang sangat ia hormati. Karya utama Kurt Godel, teorema ketidaklengkapan, adalah teorema logika paling dalam dan paling fundamental hingga saat ini.

Relativitas umum dan mekanika kuantum adalah dua teori yang paling sukses dalam sejarah sains. Prediksi-prediksi dari kedua teori tersebut sudah berhasil dikonfirmasi oleh eksperimen dengan ketelitian yang sangat tinggi. Hampir tidak ada teknologi modern yang tidak menggunakan prinsip-prinsip dari kedua teori tersebut, terutama prinsip mekanika kuantum. Penyatuan yang konsisten dari dua teori tersebut diharapkan oleh fisikawan teoretik akan menghasilkan Theory of Everything (ToE), teori yang bisa menjelaskan alam semesta dengan tuntas termasuk eksistensi Tuhan.

Calon terkuat ToE saat ini adalah M-theory. Teori ini merupakan perluasan yang menyatukan lima versi dari teori Superstring melalui konsep duality (Becker, Becker, and Schwarz, 2007). Tetapi M-theory sampai saat ini masih belum berhasil diformulasikan dengan lengkap. Formulasi modern dari M-theory biasanya menggunakan konsep Ads/CFT correspondence, yang merupakan realisasi konkret dari The Holographic Principle. 
Berdasarkan formulasi ini, fisikawan teoretik berhasil mempunyai bukti yang lebih kuat bahwa alam semesta yang diamati manusia benar-benar seperti hologram (Hanada, Hyakutake, and Goro, 2014). Oleh karena itu, realitas alam semesta yang diamati manusia adalah ilusi, sebab hanya merupakan proyeksi dari realitas yang lebih tinggi. Fenomena ini bisa diperluas ke level-level realitas yang jauh lebih tinggi dengan memakai Reflection Principle dari The Higher Infinite, yang akan dibahas dalam bagian 3 dari artikel ini.

Menurut M-theory, terdapat 11 dimensi ruang-waktu (spacetime) di alam semesta. Struktur matematika dari ruang-waktu tersebut disebut dengan Supermanifold. Alam semesta yang teramati sehari-hari melalui pancaindera hanya berdimensi 4, yakni 3 dimensi ruang dan 1 dimensi waktu. Manusia tidak bisa mengamati secara langsung dimensi ekstra dari alam semesta karena keterbatasan pancaindera. Jika seorang pengamat ingin mengamati dimensi ekstra tersebut, maka ia harus menggunakan level kesadaran manusia yang lebih tinggi (dari pancaindera), misalnya dengan menggunakan matematika. Karena fisikawan tidak bisa melakukan eksperimen dalam 11 dimensi ruang-waktu, dimensi ekstra tersebut perlu "dikompaktifikasi". Struktur matematika kompaktifikasi dari dimensi ekstra alam semesta tersebut disebut dengan Calabi-Yau manifold (Yau, and Nadis, 2012).

Menurut $M$-theory, alam semesta dan segala isinya terbuat dari objek geometri yang disebut dengan p-brane. Vibrasi dari p-brane inilah yang menciptakan semua partikel elementer yang kemudian berinteraksi satu sama lain untuk menghasilkan semua fenomena dan eksistensi yang ada di alam semesta. Semua partikel elementer yang diciptakan dari $p$-brane tersebut terhubung satu dengan yang lainnya menjadi satu kesatuan. Meskipun partikel-partikel elementer tersebut dipisahkan oleh jarak yang sangat jauh, mereka seolah-olah seperti mengetahui satu dengan yang lainnya, dan bekerja secara bersamasama dalam satu kesadaran. Fisikawan John Hagelin berspekulasi bahwa kesatuan medan partikel tersebut identik dengan level kesadaran yang dicapai oleh praktisi meditasi transendental (Hagelin, 1987). 
Saat ini semua ilmu fisika masih belum bisa menembus Planck Wall, yang merupakan pembatas peristiwa sebelum dan sesudah Planck time, yaitu $10^{-43}$ detik setelah terjadinya Big Bang. Ketika menembus Planck Wall semua besaran fisika mendekati infinity. Persoalan singularitas dalam infinity inilah yang menyebabkan semua teori fisika menjadi tidak berlaku di sana. Karena itu ilmu fisika masih belum bisa menjelaskan kondisi awal alam semesta saat dan sebelum terjadinya Big Bang. Suatu saat ilmu fisika mungkin bisa mengatasi persoalan ini ketika formulasi lengkap dari M-theory berhasil ditemukan.

Seandainya formulasi lengkap dari M-theory berhasil ditemukan, apakah gambaran realitas yang diberikan oleh teori ini adalah gambaran realitas yang paling sejati? Atau jangan-jangan gambaran realitas yang diberikan-nya juga ilusi, seperti gambaran realitas yang diberikan oleh pancaindera? Pertanyaan penting ini akan dijawab dengan tuntas dalam bagian 3 dari artikel ini.

Menurut fisikawan Max Tegmark, jika M-theory berhasil menjadi ToE maka struktur matematika dari M-theory dan alam semesta tidak bisa dibedakan satu sama lain (isomorphic). Oleh karena itu, matematika (dari $M$-theory) dan alam semesta (dan segala isinya) adalah identik. Jadi jika dilihat dari level realitas yang lebih tinggi, segala sesuatu yang ada di alam semesta dan alam semesta itu sendiri, adalah matematika. Pandangan Max Tegmark ini dikenal dengan nama "The Mathematical Universe Hypothesis" (Tegmark, 2014). Apakah The Mathematical Universe Hypothesis benar? Pertanyaan yang sangat penting ini juga akan dijawab dengan tuntas dalam bagian 3.

Sebagaimana Galileo Galilei, fisikawan teoretik memandang matematika sebagai bahasa untuk memahami realitas. Tanpa menggunakan matematika tidak mungkin manusia bisa memahami alam semesta karena semua hukum alam hanya bisa dinyatakan dengan menggunakan matematika. Stephen Hawking (Hawking, 1988: 174) pernah menanyakan apa sesungguhnya yang memberikan "ruh" kepada matematika sehingga alam semesta harus tunduk kepadanya: "What is it that breathes fire into the equations and makes a universe for them to describe?". Pertanyaan ini dijawab oleh The Mathematical Universe Hypothesis dari Max Tegmark di atas, karena 
sesungguhnya matematika bukan hanya bahasa untuk memahami realitas, melainkan juga identik dengan realitas itu sendiri.

Jika bahasa untuk menggambarkan realitas identik dengan realitas itu sendiri, maka sudah tidak ada lagi perbedaan antara subjek (yang mengamati realitas) dengan objek (realitas yang diamati oleh subjek tersebut). Dalam level ini, subjek identik dengan objek. Jika pada akhirnya subjek identik dengan objek, maka proses pemahaman terhadap realitas adalah identik dengan "proses menjadi" dari subjek ke objek, dan demikian pula sebaliknya. Pemahaman tertinggi subjek terhadap objek akan tercapai jika subjek telah mencapai sifat yang paling fundamental (atau disebut esensi) dari objek, yang tanpa sifat ini objek tersebut mustahil untuk eksis.

\section{TENTANG MATEMATIKA DAN TEOREMA KETIDAKLENGKAPAN GODEL}

Bagaimana sesungguhnya gambaran realitas yang diberikan oleh matematika? Secara prinsip semua teori matematika bisa dinyatakan atau dikode dalam sistem Zermelo-Fraenkel set theory atau disingkat dengan nama sistem ZFC, yang pada dasarnya merupakan sistem logika first-order dengan memakai aksiomaaksioma yang diformulasikan oleh Ernst Zermelo dan Abraham Fraenkel, ditambah dengan aksioma AC (Axiom of Choice). Gambaran realitas dari sistem ZFC diberikan oleh "Von Neumann Universe" (Jech, 2003: 64).

Namun berdasarkan teorema ketidaklengkapan, hasil karya yang sangat monumental dari Kurt Godel yang dibuktikannya pada tahun 1931 (Godel, 1992), sistem ZFC ini tidak lengkap. Dalam formulasinya yang paling umum (bukan formulasi asli dari Godel), teorema ketidaklengkapan menyatakan bahwa setiap sistem logika yang konsisten dan dapat menginterpretasikan aritmetika adalah tidak lengkap. Karena sistem ZFC dapat menginterpretasikan aritmetika, maka sistem ZFC tidak lengkap. Ketidaklengkapan dari sistem ZFC ini juga berarti bahwa terdapat teori matematika, meskipun teori tersebut konsisten dan bisa dinyatakan dalam sistem ZFC, teori tersebut tidak bisa ditentukan benar atau salahnya di 
dalam sistem ZFC. Jadi ada level realitas tertentu yang tidak bisa dijangkau oleh matematika.

Untuk memahami teorema ketidaklengkapan Godel, kuncinya adalah dengan memahami konsep aritmetisasi sintaksis, yaitu proses pengkodean sistem logika dengan menggunakan aritmetika (Kleene, 2009). Proses aritmetisasi sintaksis dapat juga dikerjakan lebih mudah dengan menggunakan Modal Logic (Budiyanto, 1999).

Terdapat banyak contoh realitas yang tidak bisa dijangkau oleh matematika. Contoh yang terkenal adalah realitas yang digambarkan dalam "Suslin's problem", problem matematika yang berasal dari matematikawan Rusia, Mikhail Suslin (1920). Problem ini berkaitan dengan masalah ordering dari bilangan real. Nikolai Luzin, bapak matematikawan Rusia, mengatakan bahwa Suslin's problem mustahil bisa dipecahkan oleh manusia. Luzin menyatakan bahwa mengenai Suslin's problem ini, "one will never know", manusia tidak akan pernah tahu jawabannya (Chong, 2014: 4).

Perkembangan berikutnya menunjukkan bahwa Suslin's problem ternyata memang tidak dapat dipecahkan dalam sistem ZFC, dan oleh karena itu tidak bisa dipecahkan dengan menggunakan matematika. Hal ini dapat dibuktikan dengan eksak dalam "Descriptive Set Theory". Hasil pembuktian ini juga memberikan konfirmasi kebenaran prediksi teorema ketidaklengkapan Godel. Tetapi apakah itu berarti manusia selamanya tidak bisa memecahkan Suslin's problem, seperti prediksi Luzin?

Prediksi Luzin tersebut ternyata tidak benar. Solusi dari Suslin's problem akhirnya ditemukan dengan menggunakan level infinity yang lebih tinggi dari level infinity sistem ZFC: yakni dengan menggunakan "projective determinacy" (Kanamori, 2008).

Contoh-contoh realitas lain yang tidak bisa dipecahkan oleh sistem ZFC, dan karenanya juga tidak bisa dipecahkan oleh matematika misalnya Whitehead problem, Normal Moore Space conjecture dan Kaplansky's conjecture (Foreman, and Kanamori, 2010). Selain contoh-contoh konkret fenomena ketidaklengkapan dalam matematika seperti di atas, terdapat pula beberapa contoh kongkret fenomena ketidaklengkapan dalam ilmu fisika. Beberapa contohnya 
adalah: Noncomputability Linear Operators (Pour-El, and Richards, 1983) dan Spectral Gap (Cubitt; Garcia, and Wolf, 2015).

Karena perumusan ToE tidak mungkin tanpa menggunakan matematika, dan matematika adalah tidak lengkap berdasarkan teorema ketidaklengkapan, maka ToE tidak akan pernah mungkin dibangun dalam ilmu fisika. Solusi dari fenomena ketidaklengkapan hanya bisa diperoleh dengan menggunakan level infinity yang lebih tinggi dari fenomena tersebut.

\section{PENGENALAN TENTANG METAMATEMATIKA DAN THE HIGHER INFINITE}

Riset modern tentang infinity dimulai oleh Georg Cantor (18451918). Karya yang monumental dari Cantor yaitu pembuktian bahwa terdapat tidak berhingga level-level dari infinity (Cantor's theorem). Keseluruhan struktur dari yang tidak berhingga level-level infinity tersebut dinamakan "The Higher Infinite" (Kanamori, 2008). David Hilbert, salah satu matematikawan terbesar awal abad 20, memberikan penghargaan yang sangat tinggi terhadap karya Cantor dengan mengatakan: "From the paradise, that Cantor created for us, noone can expel us".

Georg Cantor menyebut level tertinggi dari The Higher Infinite dengan nama The Absolute Infinite atau juga sering disebut dengan "Omega". Cantor mengidentifikasi Omega dengan Tuhan (Heller, and Woodin, 2011: 41). Gambaran realitas atau "universe" dari The Higher Infinite disebut dengan "Verum" atau disingkat dengan huruf V. Verum adalah proper class dari semua objek. Tidak ada eksistensi atau fenomena yang berada di luar V. Tidak ada realitas yang berada diluar V. Setiap konsepsi apapun tentang realitas selalu dapat dinyatakan dengan menggunakan $\mathrm{V}$, dengan kata lain $\mathrm{V}$ adalah "absolutely everything". Terdapat teorema yang dapat dibuktikan dengan eksak dalam Metamatematika, yang membuktikan bahwa $\mathrm{V}$ adalah benar-benar "absolutely everything". Di sini, yang dimaksud dengan Metamatematika adalah analisa Metalogika dari The Higher Infinite. 
Riset mutakhir tentang struktur The Higher Infinite menunjukkan bahwa realitas level bawah bergantung secara mutlak eksistensinya kepada realitas di atasnya, dan pada gilirannya realitas ini bergantung secara mutlak eksistensinya kepada realitas di atasnya lagi, dan demikian seterusnya. Semua realitas dibawah berkonvergen di realitas yang lebih atas. Sedangkan realitas yang di atas memproyeksikan sifat-sifat-nya kepada realitas yang dibawahnya. Pernyataan terakhir ini disebut dengan Reflection Principle dan dapat dibuktikan dengan eksak dengan menggunakan Metamatematika. Reflection Principle juga memberikan implikasi bahwa V tidak bisa dikarakterisasi dengan menggunakan level-level realitas di bawah Omega.

Hasil-hasil riset mutakhir dari The Higher Infinite juga memberikan konfirmasi (meskipun masih jauh dari lengkap) terhadap kebenaran dari persamaan $\left(^{*}\right)$ berikut ini:

$$
\text { Konsistensi }+ \text { Infinity }=\text { Kebenaran }\left(^{*}\right)
$$

Konsep "kebenaran" atau kesesuaian dengan realitas dalam persamaan di atas diberikan formulasi eksak-nya oleh Alfred Tarski. Adalah Tarski orang pertama yang berhasil mendefinisikan konsep kebenaran dengan eksak (Tarski, 1983).

Tarski juga berhasil membuktikan bahwa konsep kebenaran tidak bisa didefinisikan dalam matematika. Hasil ini disebut dengan "Tarski's Undefinability Theorem". Teorema ketidaklengkapan Godel dengan teorema undefinability Tarski adalah ekuivalen, karena teorema undefinability Tarski dapat diturunkan dari teorema ketidaklengkapan Godel, dan demikian pula sebaliknya. Kurt Godel sebenarnya sudah menemukan teorema undefinability sebelum Tarski, karena teorema undefinability sesungguhnya bisa diturunkan dengan mudah dari teorema ketidaklengkapan Godel. Mungkin karena hal itulah teorema ketidaklengkapan Godel lebih dikenal orang daripada teorema undefinability Tarski.

Meskipun konsep kebenaran tidak bisa didefinisikan dalam matematika, tetapi jika digunakan level infinity yang lebih tinggi dari level infinity dari sistem ZFC, maka definisi kebenaran dalam 
matematika, seperti yang digambarkan dalam persamaan $\left(^{*}\right)$ di atas bisa dicapai. Untuk tujuan ini, misalnya dapat digunakan Inaccessible cardinal (kappa) karena level infinity-nya lebih tinggi dari sistem ZFC. Jadi dalam sistem (ZFC + kappa) bisa didefinisikan konsep kebenaran dalam matematika. Gambaran realitas yang diberikan oleh sistem ini bisa dinyatakan dengan menggunakan Von Neumann Universe $V$ kappa, dimana kappa adalah Inaccessible cardinal, level infinity yang digunakan dalam Von Neumann universe tersebut.

Persamaan $\left(^{*}\right)$ dapat juga digunakan untuk menjelaskan fenomena yang dijelaskan dalam bagian 2 artikel ini. Penjelasannya adalah sebagai berikut: Suslin's problem adalah konsisten, karena Suslin's problem bisa dinyatakan atau dikode dalam sistem ZFC. Tetapi sistem ZFC tidak bisa menentukan kebenaran dari Suslin's problem, berdasarkan prediksi teorema ketidaklengkapan Godel. Berdasarkan persamaan $\left({ }^{*}\right)$, untuk menentukan kebenaran dari Suslin's problem diperlukan level infinity yang lebih tinggi dari level infinity sistem ZFC, yakni dengan menggunakan projective determinacy. Level infinity dari inaccessible cardinal masih belum cukup tinggi untuk digunakan menentukan kebenaran dari Suslin's problem.

Berdasarkan persamaan $\left({ }^{*}\right)$ di atas, semakin tinggi kebenaran dari realitas yang ingin dicapai, maka level infinity dalam The Higher Infinite yang diperlukan juga harus semakin tinggi. Konsistensi dalam persamaan tersebut merupakan syarat perlu dari setiap eksistensi. Berdasarkan prinsip identitas dalam Metalogika, setiap realitas harus konsisten (yang juga dikonfirmasi eksak oleh teorema kelengkapan). Karena terdapat tidak berhingga level-level dari infinity, maka juga terdapat tidak berhingga level-level kebenaran dari realitas. Semakin tinggi level realitasnya, kebenarannya juga semakin tinggi, dan mencakup kebenaran-kebenaran yang ada dibawahnya. Semua kebenaran-kebenaran dari realitas level bawah akan konvergen dalam level realitas yang lebih tinggi.

Berikut ini adalah beberapa contoh aksioma infinity level paling bawah dalam hierarki The Higher Infinite yang diurutkan berdasarkan kekuatan konsistensi: 
(i) ZFC

(ii) Inaccessible Cardinal

(iii) Mahlo Cardinal.

(iv) Weakly Compact Cardinal

(v) Indescribable Cardinal

(vi) Ramsey Cardinal

(vii) Measurable Cardinal

(viii) ...dst

Konsistensi dari Inaccessible Cardinal lebih tinggi dari konsistensi dari sistem ZFC, karena konsistensi dari sistem ZFC dapat dibuktikan dalam Inaccessible Cardinal, dan bukan sebaliknya. Konsistensi dari Mahlo Cardinal lebih tinggi dari Inaccessible Cardinal, dan demikian seterusnya. Terdapat hierarki natural dalam The Higher Infinite dari level bawah sampai yang paling tinggi. Saat ini terdapat dua program riset utama yang ditujukan untuk mengkarakterisasi hierarki dari The Higher Infinite: "Ultimate-L" (Woodin, 2017) dan "Hyperuniverse program" (Friedman, 2016).

Berdasarkan analisis Metamatematika di atas, M-theory sesungguhnya masih sangat jauh dari realitas yang paling sejati. Level dari $M$-theory adalah level infinity yang paling bawah, karena M-theory dan seluruh ilmu fisika lainnya pada prinsipnya masih bisa dikode dalam sistem ZFC. Analisa tersebut menunjukkan bahwa terdapat tidak berhingga level realitas di atas realitas yang diberikan oleh M-theory. Oleh karena itu, The Mathematical Universe Hypothesis juga tidak benar, kecuali kalau matematika diganti dengan Metamatematika.

Akan tetapi teorema ketidaklengkapan bisa diterapkan juga ke $\mathrm{V}$, sehingga $\mathrm{V}$ juga tidak lengkap. Untuk menjadikan $\mathrm{V}$ lengkap Omega tidak bisa digunakan, karena keseluruhan struktur dari $\mathrm{V}$, termasuk Omega, adalah tidak lengkap. Agar supaya $\mathrm{V}$ menjadi lengkap, maka $\mathrm{V}$ harus selalu bertransformasi secara dinamis menjadi dirinya sendiri $V^{\prime}$ (V-Prime) yang lebih lengkap. Pada gilirannya, teorema ketidaklengkapan bisa juga diterapkan ke $V^{\prime}$, sehingga $V^{\prime}$ harus bertransformasi menjadi dirinya sendiri V" (V-Double Prime) yang jauh lebih lengkap lagi, dan demikian seterusnya sampai tidak 
berhingga. Ketika $\mathrm{V}$ menjadi lengkap, saya menyebut $\mathrm{V}$ dengan nama "The True Absolute". Tidak ada level realitas yang lebih tinggi dan yang lebih sempurna dari The True Absolute. Berdasarkan hasil riset yang saya kerjakan tetapi masih belum final, terdapat prinsip Metalogika tertentu yang dapat menentukan keadaan esensi dengan tepat (syarat perlu dan cukup) ketika V merealisasikan The True Absolute. Pembahasan tentang hal ini berada sangat jauh dari ruang lingkup artikel ini karena mempersyaratkan Metamatematika level paling tinggi.

\section{REALITAS MENURUT JALALUDDIN RUMI}

Jalaluddin Rumi (1207 - 1273) adalah penyair sufi terbesar sepanjang zaman. Puisi Rumi yang berjudul "A Garden Beyond Paradise" dipilih sebagai fokus pembahasan karena dipandang cukup mewakili pengalaman mistik Rumi tentang realitas (Star and Shiva, 1992). Puisi tersebut akan ditafsirkan dengan memakai The Higher Infinite. Penafsirannya akan dibagi menjadi enam bagian sebagai berikut.

\section{A Garden Beyond Paradise}

Everything you see has its roots

in the unseen world.

The forms may change,

yet the essence remains the same.

Every wondrous sight will vanish, every sweet word will fade.

But do not be disheartened,

The Source they come from is eternal--

growing, branching out,

giving new life and new joy.

Why do you weep?

That Source is within you, 
14 Jurnal Filsafat, Vol. 28, No. 1 Februari 2018

and this whole world

is springing up from it.

The Source is full,

its waters are ever-flowing;

Do not grieve, drink your fill!

Don't think it will ever run dry--

This is the endless Ocean!

From the moment you came into this world, a ladder was placed in front of you

that you might transcend it.

From earth, you became plant, from plant you became animal.

Afterwards you became a human being, endowed with knowledge, intellect and faith.

Behold the body, born of dust-how perfect it has become!

Why should you fear its end?

When were you ever made less by dying?

When you pass beyond this human form, no doubt you will become an angel and soar through the heavens!

But don't stop there.

Even heavenly bodies grow old.

Pass again from the heavenly realm and plunge into the ocean of Consciousness.

Let the drop of water that is you become a hundred mighty seas. 
But do not think that the drop alone

becomes the Ocean--

the Ocean, too, becomes the drop!

(1) Everything you see has its roots in the unseen world. The forms may change, yet the essence remains the same. Every wondrous sight will vanish, every sweet word will fade. But do not be disheartened, The Source they come from is eternal-growing, branching out, giving new life and new joy.

Semua realitas yang terlihat adalah proyeksi dari level realitas yang lebih tinggi. Hal ini bisa dibuktikan dengan menggunakan Reflection Principle. "The Source", yang disebutkan oleh Rumi, merujuk kepada Tuhan, yang merupakan The Absolute Infinite, yaitu sumber dari segala sumber sifat kesempurnaan. Tuhan memproyeksikan sifat-sifat Nya ke level-level realitas yang lebih rendah. Jadi semua realitas yang teramati bisa ditelusuri asal-usulnya dari Tuhan. Realitas yang teramati tersebut mungkin selalu berubah, tetapi esensi dari sifat-sifat Tuhan selalu sama. Proyeksi sifat-sifat Tuhan tersebut terjadi secara terus-menerus, ke segala arah, ke semua level-level realitas, untuk mencerminkan kesempurnaan Tuhan.

(2) Why do you weep? That Source is within you, and this whole world is springing up from it.

Manusia adalah tujuan utama dari proses proyeksi sifat-sifat Tuhan. Hanya manusia yang bisa menerima semua proyeksi dari sifat-sifat Tuhan tersebut. Hanya Manusia yang bisa mencerminkan semua sifat-sifat Tuhan dengan sempurna. Ketika manusia mencapai level ini, sifat-sifat Tuhan tersebut di refleksikan kembali ke seluruh alam semesta, ke seluruh level-level realitas. Hal ini juga bisa dijelaskan dengan menggunakan Reflection Principle.

(3) The Source is full, its waters are ever-flowing; Do not grieve, drink your fill! Don't think it will ever run dry - This is the endless Ocean! 
Tuhan yang disimbolkan oleh Rumi dengan "The Ocean", seperti lazimnya dalam literatur tasawuf, adalah The Absolute Infinite. Sebagaimana yang telah dijelaskan dalam bagian 1 puisi di atas, The Ocean merupakan sumber dari segala sumber dari semua sifat kesempurnaan. Sumber tersebut tidak akan pernah habis dalam mencerminkan sifat-sifat Nya. Hal ini karena terdapat tidak berhingga level-level infinity dalam Verum V.

(4) From the moment you came into this world, a ladder was placed in front of you that you might transcend it. From earth, you became a plant, from the plant you became an animal. Afterwards, you became a human being, endowed with knowledge, intellect, and faith. Behold the body, born of dusthow perfect it has become! Why should you fear its end? When were you ever made less by dying? When you pass beyond this human form, no doubt you will become an angel and soar through the heavens! But don't stop there. Even heavenly bodies grow old.

Manusia memiliki potensi untuk mencapai realitas yang paling tinggi. Untuk merealisasikan potensi tersebut, manusia harus mengalami proses evolusi dan involusi (Baba, 1968; Bentov, 1981; Bentov, 2000). Proses evolusi adalah proses yang sangat panjang yang harus dilalui oleh kesadaran dari jiwa manusia, dari level realitas paling rendah, ke level realitas manusia-jasmani.

Sedangkan proses involusi adalah proses yang sangat panjang yang juga harus dilalui oleh kesadaran dari jiwa manusia dari level realitas manusia-jasmani ke manusia-ruhani, sampai manusia mencapai surga. Tetapi surga bukanlah akhir dari segalanya, karena sesungguhnya level surga masih dalam level realitas ilusi. Masih terdapat tidak berhingga level realitas yang lebih tinggi dari level surga. Sementara banyak manusia yang masih terperangkap kenikmatan semu dalam surga, manusia yang sejati seharusnya meneruskan perjalanan ruhaninya menuju level realitas yang paling tinggi. 
(5) Pass again from the heavenly realm and plunge into the ocean of Consciousness. Let the drop of water that is you become a hundred mighty seas.

Tujuan perjalanan ruhani manusia adalah untuk menyatu dengan Tuhan. Terdapat paling tidak empat konsep yang berbeda dalam menafsirkan "penyatuan" dengan Tuhan sebagai berikut:

1. Wahdatul Muthlaqah (Ibn Sab'in),

2. Advaita Vedanta (Adi Shankara),

3. Wahdatul Wujud (Ibn Arabi),

4. Wahdatul Shuhud (Ahmad Sirhindi),

Semua keempat penafsiran tersebut konsisten dan dapat dinyatakan dalam The Absolute Infinite. Oleh karena itu, semua penafsiran tersebut benar, sesuai dengan level-nya masing-masing dalam The Absolute Infinite.

Menurut Ibn Sab'in, tidak ada perbedaan fundamental antara wujud Tuhan dengan wujud manusia (Westerveld, 2015: 114). Sedangkan menurut Adi Shankara, hakekat Tuhan yang paling tinggi, yang disebut dengan "Brahman", adalah identik dengan hakekat manusia, yang disebut dengan "Atman" (Isayeva, 1993: 127). Dalam tasawuf Brahman juga disebut dengan banyak nama, seperti Wara-ulWara, Ghaib-ul-Ghaib, Al-Ama, atau Ahadiyah. Sedangkan Atman dalam tasawuf biasanya juga disebut dengan nama Sirrus-Sirr, Khafi, atau Akhfa. Jika dilihat dalam keseluruhan struktur dari Verum V, hanya ada satu wujud yakni wujudnya The Absolute Infinite. Brahman adalah The Absolute Infinite. Manusia yang sudah berhasil mencapai atau merealisasikan The Absolute Infinite akan menemukan hakekat dirinya sendiri (Atman), yang menurut Ibn Sab'in dan Adi Shankara adalah identik dengan hakekat Tuhan (Brahman). Perbedaan antara Ibn Sab'in dan Adi Shankara kelihatannya hanya pada persoalan epistemologi.

Sementara itu menurut Ibn Arabi, meskipun terdapat hanya satu wujud, kesatuan antara Tuhan dan manusia tidaklah mutlak, 
artinya masih bisa dibedakan antara Tuhan dan manusia. Ketika level ruhani manusia cukup tinggi, dia bisa melihat keseluruhan realitas, termasuk diri dia sendiri dan Tuhan, sebagai satu kesatuan wujud tetapi dia masih melihat perbedaan antara hakekat Tuhan dan hakekat diri-nya sendiri. Penafsiran ini juga benar kalau dilihat di dalam (bukan keseluruhan) dari struktur V. Bahkan dalam level-level bawah dari $\mathrm{V}$, manusia sesungguhnya sudah bisa melihat kesatuan dari semua wujud, meskipun masih jauh dari sempurna, misalnya seperti yang dicapai oleh ilmu fisika yang dijelaskan dalam bagian 1 artikel ini.

Sedangkan menurut Ahmad Sirhindi, sesungguhnya tidak ada penyatuan wujud antara manusia dan Tuhan karena wujud Tuhan dan wujud manusia berbeda secara fundamental. Penafsiran ini juga benar jika dilihat di dalam (bukan keseluruhan) struktur V, karena manusia akan menemukan level-level realitas yang tidak berhingga di dalam V, meskipun struktur V itu sendiri adalah tunggal. Dalam level infinity yang lebih tinggi, level wujudnya juga lebih tinggi, dan mencakup level-level dibawahnya. Tentu terdapat perbedaan antara level realitas bawah dan level realitas diatasnya.

Hanya ketika manusia mencapai dan merealisasikan The Absolute Infinite sajalah, kesatuan mutlak menjadi mungkin, seperti dalam penafsiran Ibn Sab'in dan Adi Shankara. Perealisasian ini adalah suatu keniscayaan dalam analisa Metalogika karena sebagai konsekuensi dari sifat-sifat transformasi dari V. Seperti yang dijelaskan dalam bagian 1 di alinea terakhir dari artikel ini, proses memahami realitas adalah proses menjadi. Semakin tinggi proses pemahamannya, maka semakin tidak bisa dibedakan antara subjek yang memahami dan objek realitas yang dipahami oleh subjek tersebut.

Selain penafsiran penyatuan dengan Tuhan dalam tradisi Islam-Tasawuf dan Advaita Vedanta seperti di atas, terdapat pula penafsiran dari tradisi agama lain. Misalnya dalam tradisi Kristen, Meister Eckhart adalah salah satu mistikus terbesar dan yang paling berpengaruh. Tentang konsep penyatuan dengan Tuhan, pandangan Eckhart hampir sama dengan Ibn Arabi, yakni dalam level penyatuan yang paling tinggi masih dapat dibedakan antara hakekat Tuhan dan 
hakekat manusia (Isayeva, 1993: 119). Menurut Eckhart, perbedaan antara Godhead dan God adalah seperti perbedaan antara langit dan bumi. God disini adalah Tuhan Trinitas. Sedangkan Godhead adalah asal usul dari God, jadi level realitas Godhead jauh lebih tinggi dari God. Dalam tradisi Advaita Vedanta, Godhead ini disebut dengan Brahman, atau yang lebih tepat lagi disebut dengan Nirguna Brahman, atau Para Brahman, yakni Brahman yang paling tinggi.

Seperti yang dijelaskan dalam bagian 3 dari artikel ini, tidak ada konsepsi tentang realitas yang tidak dapat dinyatakan dengan menggunakan The Higher Infinite. Misalnya konsep tentang "Ayn Sof", yang menurut tradisi Kabbalah (tradisi mistik dalam agama Yahudi) adalah level realitas yang paling tinggi, dapat juga dinyatakan dalam The Absolute Infinite. Pada kenyataannya arti harfiah dari Ayn Sof dalam bahasa Hebrew adalah infinity. Sedangkan dalam agama Buddha, level realitas yang paling tinggi disebut dengan "Dharmakaya". Konsepsi tentang Dharmakaya dapat juga dinyatakan dalam The Absolute Infinite. Tetapi dalam penalaran harus dibuat berhati-hati untuk tidak menyamakan Brahman dengan Dharmakaya, meskipun kedua konsep tersebut dapat dinyatakan dalam The Absolute Infinite. Hanya konsepsi Dharmakaya dari aliran Buddha Mahayana yang dekat dengan konsepsi Brahman dari Advaita Vedanta (Loy, 1997: 28). Semua konsepsi tentang realitas tertinggi dari semua agama dan kepercayaan dapat dinyatakan dalam levellevel infinity dari The Absolute Infinite.

Dalam level penyatuan dengan Tuhan, tidak ada bahasa manusia yang bisa menggambarkan pengalaman penyatuan tersebut, kecuali hanya dengan menggunakan metamatematika level tinggi. Oleh karena itu, tidak ada lagi yang perlu dibahas disini. Nabi Muhammad bahkan pernah memperingatkan untuk tidak membicarakan hal-hal esoteris tingkat tinggi semacam ini kepada orang awam karena hanya akan menimbulkan kesalahfahaman.

Berbeda dengan para mistikus besar yang lain, Ibn Sab'in memandang "The Intellectual Principle" sebagai prinsip tertinggi dari semua eksistensi (Casewit, 2008: 7). Dengan demikian adalah logika yang berperan paling penting dalam perealisasian kebenaran paling 
sejati, dan bukan kekuatan "cinta ilahiah" seperti misalnya dalam pandangan Rumi. Logika yang dimaksud disini adalah logika transendental yang menembus infinity, atau juga disebut Metalogika, jadi seharusnya tidak direduksi hanya menjadi pemikiran rasional yang terbatas. Saya setuju dengan pandangan Ibn Sab'in ini karena The True Absolute sesungguhnya dapat dipandang sebagai "The Ultimate Intellectual Principle".

(6) But do not think that the drop alone becomes the Ocean - the Ocean, too, becomes the drop!

Penyatuan manusia dengan Tuhan seperti yang dijelaskan dalam bagian (5) di atas bukanlah akhir dari segalanya. Setelah seorang manusia menyatu dengan Tuhan, Tuhan pada gilirannya menyatu dengan Manusia. Inilah level dari Avatar, menurut Meher Baba (Baba, 1968), sedangkan dalam khazanah tasawuf, konsep yang paling dekat adalah level dari insan kamil (Al-Arabi, 1980), yakni level manusia sempurna. Menurut analisa saya dalam bagian 3 dari artikel di alinea terakhir di atas, hal ini pun sesungguhnya masih belum akhir dari segalanya. Level Avatar atau insan kamil ini pun sesungguhnya bukanlah level yang paling sempurna, karena masih amat sangat jauh dari The True Absolute.

Karena itu, bagian (6) dari puisi Rumi di atas sesungguhnya masih jauh dari lengkap. Seharusnya tidak hanya "The Ocean" menjadi "The Drop", tetapi juga "The Ocean" menjadi "The Ocean Prime", dan kemudian menjadi "The Ocean Double-Prime", dan demikian seterusnya sampai tidak berhingga. Proses ini terjadi terus menerus secara dinamis sampai mencapai The True Absolute.

\section{SIMPULAN}

Teorema ketidaklengkapan memberi implikasi bahwa realitas itu "konsisten" atau "lengkap". Tidak bisa keduanya "konsisten dan lengkap" pada waktu yang bersamaan, kecuali jika memakai level infinity yang lebih tinggi dari realitas tersebut. Berdasarkan analisis sains dan metafisika, realitas pasti harus konsisten, karena jika tidak, maka tidak mungkin akan ada eksistensi. Hal ini dikarenakan dua 
eksistensi yang tidak konsisten, atau berkontradiksi satu sama lain, merupakan suatu kemustahilan. Inilah intisari dari prinsip identitas dalam metafisika dan Metalogika.

Teorema ketidaklengkapan juga memberikan implikasi bahwa mustahil sains dapat menjelaskan realitas dengan tuntas. Untuk mengatasi fenomena ketidaklengkapan dari realitas, level infinity yang lebih tinggi dari realitas tersebut mutlak diperlukan.

Keseluruhan realitas adalah identik dengan Verum V. Tidak ada konsepsi tentang realitas yang tidak dapat dinyatakan dengan menggunakan V. Sebagaimana level-level realitas yang berada di dalam $\mathrm{V}$, keseluruhan struktur $\mathrm{V}$ juga tidak lengkap, berdasarkan teorema ketidaklengkapan. Oleh karena itu, puisi Rumi "A Garden Beyond Paradise" juga tidak lengkap, karena realitas tertinggi menurut Rumi yang disebut dengan "The Ocean" sesungguhnya dapat juga dinyatakan dalam The Absolute Infinite atau V. Supaya Verum V menjadi lengkap, maka $\mathrm{V}$ harus bertransformasi secara dinamis menjadi dirinya sendiri yang lebih lengkap. Jika dilihat di dalam $\mathrm{V}$ (bukan keseluruhan V), V itu sendiri sesungguhnya sudah lengkap dan sempurna, karena setiap fenomena ketidaklengkapan di dalam $\mathrm{V}$ selalu dapat ditemukan solusinya dengan menggunakan level-level infinity dari $\mathrm{V}$. Tetapi jika dilihat dari keseluruhan $\mathrm{V}, \mathrm{V}$ sesungguhnya masih amat jauh dari lengkap. Dengan demikian, tujuan sejati dari semua eksistensi, disadari atau tidak disadari, semuanya adalah diarahkan untuk mencapai kelengkapan dan kesempurnaan yang paling tinggi dari $\mathrm{V}$, yakni untuk merealisasikan The True Absolute. Inilah jawaban final dari pertanyaan terbesar semua filsafat: Why is there something rather than nothing?

Kesimpulan ini akan ditutup dengan empat kutipan yang diambil dari literatur filsafat-tasawuf yang diharapkan dapat membantu pembaca dalam memahami kesimpulan di atas. Penulis kutipan tersebut tentu saja belum tentu setuju dengan kesimpulan di atas, tetapi kutipan tersebut mengandung esensi yang paling dekat (meskipun sangat jauh dari identik) dengan esensi dari kesimpulan artikel ini. Ibn Arabi, penulis kutipan pertama, sangat mungkin tidak akan setuju dengan kesimpulan di atas karena penafsiran kesatuan 
mutlak dari Ibn Sab'in telah mendapatkan pembenaran dari artikel ini, sementara Ibn Arabi sendiri tidak menyetujui penafsiran tersebut.

(i) Kesempurnaan adalah cinta kepada kesempurnaan itu sendiri. Dengan demikian, pengetahuan Tuhan tentang diri-Nya sendiri, yang berada di luar jangkauan kebutuhan dunia dan segala isinya, adalah untuk diri-Nya sendiri. Selalu akan tetap ada penyempurnaan pengetahuan diri melalui pengetahuan terhadap yang relatif, yang dalam kemunculannya berasal dari esensiesensi kosmos. Kesempurnaan yang lengkap hanya dapat dicapai melalui pengetahuan terhadap yang relatif dan yang abadi sekaligus (Al-Arabi, 1980: 257).

(ii) Tuhan, dalam kondisi asalnya sama sekali tidak menyadari eksistensi maupun hakekat ketidakberhinggan-Nya, meskipun Dia ada secara abadi dan tidak berhingga. Tuhan memerlukan kesadaran tentang Realitas-Nya untuk dapat merealisasikan diriNya yang Tak Terbatas, Abadi dan Tak Berhingga (Baba, 1968:77). (iii) Tanpa mampu menciptakan suatu bentuk kesadaran yang setara dengan-Nya dalam segala kualitas, Dia mungkin tidak akan pernah mengetahui hakikat diri-Nya yang sejati. Oleh karena itulah Dia menciptakan makhluk-makhluk yang seberagam mungkin, serta menciptakan peristiwa-peristiwa dan keadaan yang juga seberagam mungkin, supaya semua makhluk Nya tersebut menjalani setiap kemungkinan yang ada dan kemudian melakukan interaksi dalam setiap keadaan yang mungkin. Dari situlah Dia akan mengetahui apa yang dapat Dia lakukan dan akhirnya akan mengetahui siapa diri-Nya (Bentov, 1981:195).

(iv) Adalah benar mengatakan bahwa Tuhan menciptakan Dunia, sebagaimana benar pula mengatakan bahwa Dunia menciptakan Tuhan (Whitehead, 1978: 348).

\section{DAFTAR PUSTAKA}

Al-Arabi, Ibn, 1980, The Bezels of Wisdom, translated by R. W. J. Austin, Paulist Press.

Baba, Meher, 1968, God Speaks: The Theme of Creation and Its Purpose, Dodd, Mead and Company, New York. 
Becker, Katrin; Becker, Melanie, and Schwarz, John, 2007, String theory and M-theory: A modern introduction, Cambridge University Press, New York.

Bentov, Itzhak, 1981, Stalking the Wild Pendulum, Bantam Books, New York.

, 2000, A Brief Tour of Higher Consciousness, Destiny Books, Rochester.

Budiyanto, Agus Hasan, 1999, Godel's Incompleteness Theorem and Modal Logic, Preprint.

Casewit, Yousef Alexander, 2008, The Objective of Metaphysics in Ibn Sab 'in's Answers to the Sicilian Questions, the Journal of the Iqbal Academy, Pakistan.

Chong, Chitat; Feng, Qi and Slaman, Theodore T., 2014, Infinity and Truth, World Scientific, Singapore.

Cubitt, T.S.; Garcia, P.D., and Wolf, M.M., 2015, Undecidability of the Spectral Gap, Nature 528, 207-211.

Foreman, Matthew and Kanamori, Akihiro, Editors, 2010, Handbook of Set Theory, Springer Verlag, New York.

Friedman, Sy, 2016, Evidence for Set-Theoretic Truth and the Hyperuniverse Programme, IFCoLog Journal of Logics and their Applications, Vol. 3, No. 4.

Godel, Kurt, 1992 On Formally Undecidable Propositions of Principia Mathematica And Related Systems, translated by B. Meltzer. Dover reprint of the 1962 Basic Books edition.

Hagelin, John S., 1987, Is Consciousness the Unified Field? A Field Theorist's Perspective, Modern Science and Vedic Science, 1, pp. 2987.

Hanada, Masanori, Hyakutake, Yoshifumi, Ishiki, Goro; Nishimura, 2014, Holographic description of a quantum black hole on a computer", Science, 344 (6186): 882-5.

Hawking, Stephen, 1988, A Brief History of Time, Bantam Books, New York. ,2002, Godel and the End of Physics, Dirac Lecture.

Heller, Michael and Woodin, W. Hugh, 2011, Infinity: New Research Frontiers, Cambridge University Press, New York.

Isayeva, Natalia, 1993, Shankara and Indian Philosophy, SUNY press, Albany.

Jech, Thomas, 2003, Set Theory, Third Edition, Springer Verlag, New York. Kanamori, Akihiro, 2008, The Higher Infinite, Springer Verlag, New York.

Kleene, Stephen Cole, 2009, Introduction to Metamathematics, Ishi Press, New York. 
Loy, David, 1997, Nonduality: A Study in Comparative Philosophy, Humanity Books.

Newton, Isaac, 2013, The Principia: Mathematical Principles of Natural Philosophy, Snowball Publishing.

Pour-El, Marian Boykan, and Richards, Ian, 1983, Noncomputability in Analysis and Physics: A Complete Determination of the Class of Noncomputable Linear Operators, Advances in Mathematics 48, 4474.

Rosenblum, Bruce and Kuttner, Fred, 2006, Quantum Enigma: Physics Encounters Consciousness, Oxford University Press, New York.

Star, Jonathan and Shiva, Shahram, 1992, A Garden Beyond Paradise: The Mystical Poetry of Rumi, Bantam Books, New York.

Susskind, Leonard, 1995, The World as a Hologram. Journal of Mathematical Physics. 36 (11): 6377-6396.

Tarski, Alfred, 1983, Logic, Semantics, Metamathematics: Papers from 1923 to 1938 by Alfred Tarski, Corcoran, J., ed. Hackett. 1st edition edited and translated by J. H. Woodger, Oxford University Press.

Tegmark, Max, 2014, Our Mathematical Universe: My Quest for the Ultimate Nature of Reality, First Edition, Vintage Books, New York.

Yau, Shing-Tung, and Nadis, Steve, 2012, The Shape of Inner Space: String Theory and the Geometry of the Universe's Hidden Dimensions, Basic Books, Cambridge.

Yourgrau, Palle, 2006, A World Without Time: The Forgotten Legacy of Godel and Einstein, Basic Books, Cambridge.

Westerveld, Govert, 2015, Ibn Sab'in of the Ricote Valley; the First and Last Islamic Place in Spain, Lulu.

Whitehead, Alfred North, 1978, Process and Reality: An Essay in Cosmology, Corrected Edition, David Ray Griffin and Donald W. Sherburne (eds.), Free Press, New York.

Woodin, W, 2017, In Search of Ultimate-L: The 19th Midrasha Mathematical Lectures, The Bulletin of Symbolic Logic, 23(1), 1109. 